\title{
SOSIALISASI MINI-CEX BAGI PERAWAT DI RSU SARI MUTIARA LUBUK PAKAM
}

\author{
Siska Evi Martina ${ }^{1}$, Agnes Silvina Marbun ${ }^{2}$, Rinco Siregar ${ }^{3}$ \\ 1,2,3 Universitas Sari Mutiara Indonesia \\ E-mail : siskaevi21@gmail.com
}

\begin{tabular}{ll}
\hline Article History: & Abstract: Perawat harus mampu \\
Received: 24-03-2021 & memfasilitasi mahasiswa untuk mencapai \\
Revised: 15-04-2021 & kompetensi yang telah ditetapkan. Saat ini \\
Accepted: 27-04-2021 & metode pembimbingan dan evaluasi kinerja \\
& klinik merujuk pada pengembangan \\
& keterampilan mahasiswa. Hal ini dikenal \\
& dengan Mini-Cex. Namun masih banyak \\
& perawat yang tidak paham tentang Mini- \\
& Cex. Tujuan kegiatan ini adalah untuk \\
& meningkatkan pengetahuan perawat RSU \\
& Sari Mutiara Lubuk Pakam tentang Mini- \\
& Cex. Metode kegiatan ini adalah sosialisasi, \\
& rpesentasi dan diskusi. Hasil kegiatan ini \\
& menunjukan sebanyak 15 perawat \\
& berpartisipasi aktif dalam kegiatan \\
& pengabdian masyarakat ini.Sebanyak 73,4 \\
& \% menunjukan pengetahuan kurang \\
& sebelum kegiatan dan 86,6 \% pengetahuan \\
& baik setelah mengikuti sosialisasi Mini-Cex. \\
\hline
\end{tabular}

\section{Pendahuluan}

Kegiatan di lembaga pendidikan kesehatan yang perlu dilakukan evaluasi, salah satunya adalah kegiatan belajar pada pendidikan klinik. Pada kegiatan ini mahasiswa menampilan kemampuan professional untuk pencapaian pembelajaran praktik sebesar $60 \%$ sesuai dengan kurikulum pendidikan kesehatan sehingga evaluasi tahap klinik ini perlu disusun dengan baik dan berkesinambungan untuk mencapai kompetensi yang diharapkan (Nursalam, 2011).

Howley menjelaskan bahwa pengamatan keterampilan klinis di rumah sakit sangat terbatas karena sulit untuk menyesuaikan waktu antara preceptor dan mahasiswa. Keterbatasan pengamatan selama praktik klinis memberikan efek mahasiswa tidak mendapatkan feedback yang konstruktif dan efektif dari hasil keterampilan klinisnya, sehingga peningkatan keterampilan klinis sulit dicapai.

Terdapat beberapa metode evaluasi klinik pada pendidikan klinik yaitu observasi, 
tertulis(laporan), lisan (viva-voce), objective structured clinical examination (OSCE), MiniCex, multiSource feedback (MSF), case based discussion (CBD) dan direct observation of procedural skills (DOPS). Tetapi, Mini-Cex meruakan metode yang paling efektif karena memilki ketepatan yang lebih tinggi dalam penilaian keterampilan klinis dan cukup efektif dalam menilai performa mahasiswa pada level "does". Metode ini memiliki beberapa kelebihan seperti validitas dan reabilitas yang baik, memperoleh feedback dari preceptor untuk memperbaiki performanya, memberikan kesempatan yang banyak pada mahasiswa untuk menunjukkan kemampuannya pada berbagai kasus, setting dan langsung dengan pasien.

World Health Organization (WHO) menjelaskan bahwa Mini-Cexmemiliki keterlaksanaan (feasibility) baik bagi mahasiswa dan preceptor dalam pendidikan kesehatan, dan dapat memenuhi kebutuhan proses pembelajaran praktik sebesar $60 \%$ sehingga tenaga kesehatan kompeten dalam memberikan pelayanan kesehatan.

Lembar penilaian dalam Mini-Cex pertama kali dikembangkan oleh Norcini (2003) dari American Board of Internal Medicine (ABIM) yang sudah dinyatakan valid dan reliable untuk mengukur keterampilan klinis. Mini-Cexmemiliki komponen penilaian yang menyeluruh sehingga melatih keterampilannya dengan memperbanyak interaksi dengan pasien. Penilaian Mini-Cexbersifat formatif dan feedback yang konstruktif dapat membantu proses pembelajaran klinik.

Bentuk format feedback pada Mini-Cex yang digunakan di pendidikan kedokteran perlu dimodifikasi sesuai kebutuhan perawat dan bidan sehingga pelaksanaannya sebagai assesment lebih tepat dan mampu mengarahkan mahasiswa untuk merencanakan peningkatan keterampilan klinis yang optimal.

Penelitian Tokode \& Dennick (2013) menjelaskan persepsi mahasiswa terhadap penggunaan Mini-Cex. Hasilnya menunjukkan bahwa mahasiswa memiliki pengalaman yang positif untuk keterampilan klinis.

Hal ini didukung oleh penelitian kualitatif yang dilakukan Sulistiawati (2015) mengeksplorasi respon belajar mahasiswa terhadap umpan balik yang diberikan dalam MiniCex. Mahasiswa merasa lebih dihargai dan merasa lebih semangat untuk lebih baik lagi setelah mendapat umpan balik sesuai metode Mini-Cex. Penelitian yang dilakukan Martina \& Simanjuntak (2020) bahwa Mini-Cex signifikan meningkatkan keterampilan mahasiswa keperawatan tahap klinik. 
Berdasarkan diskusi dengan bagian pendidikan dan pelatihan beserta kepala bidang keperawatan RSU Sari Mutiara Lubuk Pakam bahwa perawat belum terinformasi tentang Mini-Cex. Sedangkan dari sisi dosen pembimbing praktek mahasiswa sangat dibutuhkan kerja sama dan pemahaman yang sama terkait metode bimbingan mahasiswa di laha praktek. Maka dari itu perawat-perawat di RSU Sari Mutiara membutuhkan pengetahuan dan penyegaran informasi terkait Mini-Cex. Tujuan kegiatan ini adalah untuk meningkatkan pengetahuan perawat RSU Sari Mutiara Lubuk Pakam tentang MINI-CEX . Sehingga proses praktek mahasiswa keperawatan di RSU Sari Mutiara Lubuk Pakam dapat berjalan dengan baik.

\section{Metode}

Kegiatan pengabdian kepada masyarakat ini dilakukan melalui pendekatan sosialisasi Mini-Cex bagi perawat di RSU Sari Mutiara Lubuk Pakam. Sosialisasi Mini-Cex ini meliputi pejelasan latar belakang dan tujuan Mini-Cex, Konsep Mini-Cex, Prosedur Mini-Cex dan Manfaat Mini-Cex dalam keperawatan.

Pelaksanaan pemberian materi kepada perawat secara langsung dilakukan selama 2 (dua) hari dari jam jam 09.00 sampai jam 14.00 WIB.

Sebelum dilakukan sosialisasi diadakan Pretest terkait pengetahuan perawat tentang metode-metode bimbingan dalam keperawatan dan tentang Mini-Cex.

Tempat pelaksanaan kegiatan yaitu di Aula RSU Sari Mutiara Lubuk Pakam dengan sasaran perawat yang bertugas di ruang perawatan, Unit Gawat Darurat, ruang perawatan anak, Kamar bersalin, kamar bedah dan ruang perawatan maternal, dan unit rawat jalan. Sebanyak 15 perawat sebaga perwakilan dari setiap unit kerja.

Metode penyampaian materi dilakukan secara interaktif. Kegiatan sosialisasi dibuka secara resmi oleh Kepala Bidang Keperawatan. Materi disampaikan dengan detail dan diskusi dua arah. Pada akhir setiap sesi selalu diberikan kesempatan untuk bertanya dan berdiskusi. Pada akhir sesi dilakukan diskusi kelompok yang di hari kedua setiap kelompok mendemonstrasikan hasil diskusi. Pada akhir kegiatan pengabdian masyarakat ini dilakukan post-test untuk mengukur perubahan pengetahuan peserta sebelum dan setelah kegiatan.

\section{Hasil}

Proses pelaksanaan kegiatan ini dibagi menjadi 3 (tiga) bagia yaitu persiapan, 
pelaksanaan dan evaluasi. Kegiatan persiapan diawali dengan penyusunan proposal kegiatan dan mendapatkan ijin dari Univeristas Sari Mutiara Indonesia, lalu mengajukan permohonan ijin ke Direktur RSU Sari Mutiara Lubuk Pakam. Berdiskusi untuk mengatur jadwal kegiatan dengan kepala bidang keperawatan.

Kegiatan pelaksanaan diawali dengan pre-test, penjelasan latar belakang kegiatan dan tujuan kegiatan, penjelasan rundown dan topik kegiatan. Penjelasan amteri secara detail melalui presentasi dan diskusi, diskusi dalam kelompok kecil dan simulasi hasil diskusi.

Kegiatan evaluasi yaitu melalui post-test dan reflexi kegiatan yang dilaksanakan.

\section{Tingkat Pengetahuan Perawat}

Tabel 1. Hasil Pre-test tentang Mini-Cex

\begin{tabular}{lcc}
\hline Pengetahuan & $\mathrm{n}$ & $\%$ \\
\hline Baik & 4 & 26,6 \\
Kurang & 11 & 73,4 \\
\hline
\end{tabular}

Berdasarkan tabel 1, tingkat pengetahuan perawat tentang Mini-Cex mayoritas masih kurang $(73,4 \%)$ dan hanya $26,6 \%$ perawat yang memiliki pengetahuan baik tentang Mini-Cex. Hal ini berkaitan dengan hasil diskusi sebelum pelaksanaan kegiatan bahwa kegiatan sosialisasi atau pelatihan tentang Mini-Cex belum pernah diadakan dan mayoritas perawat tidak tahu tentang Mini-Cex.

Setelah dilakukan kegiatan pengabidan masyarakat tentang sosialisasi Mini-Cex didapatkan hasil peningkatan pengetahuan perawat, sebanyak 86,6\% perawat menunjukan pengetahuan baik tentang Mini-Cex dan hanya 13,4 \% perawat yang pengetahuan kurang (Tabel 2).

Tabel 2. Hasil Post test tentang Mini-Cex

\begin{tabular}{lcc}
\hline \multicolumn{1}{c}{ Pengetahuan } & $\mathrm{n}$ & $\%$ \\
\hline Baik & 13 & 86,6 \\
Kurang & 2 & 13,4 \\
\hline
\end{tabular}

\section{Pemaparan Materi}

Penjelasan materi secara detail mencakup tentang konsep Mini-Cex, Prosedur, Metode, Tools Mini-Cex. Penjelasan menggunakan power point yang menarik dengan contoh 
berbagai metode bimbingan prektek mahasiswa keperawatan. Peserta terlihat antusia, menyimak dan berpartisipasi dalm diskusi. Diskusi dilakukan dengan dua arah, artinya diberikan kesempatan bagi peserta untuk membagikan pengalaman selama ini dalam prose praktek mahasiswa keperawatan dan kendala yang dihadapi. Secara bersama mencari solusi yang tepat dan mengembangkan pemahaman tentang Mini-Cex. Hal tesebut telihat pada gambar 1dan Gambar 2.

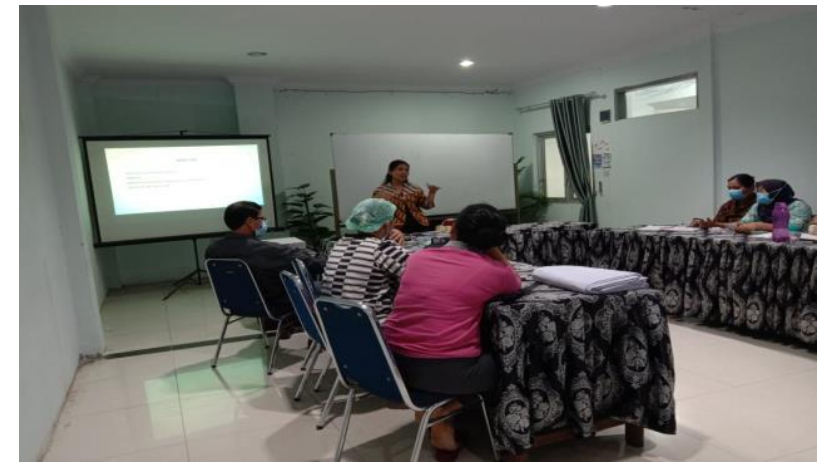

Gambar 1. Penjelasan Materi Mini-Cex

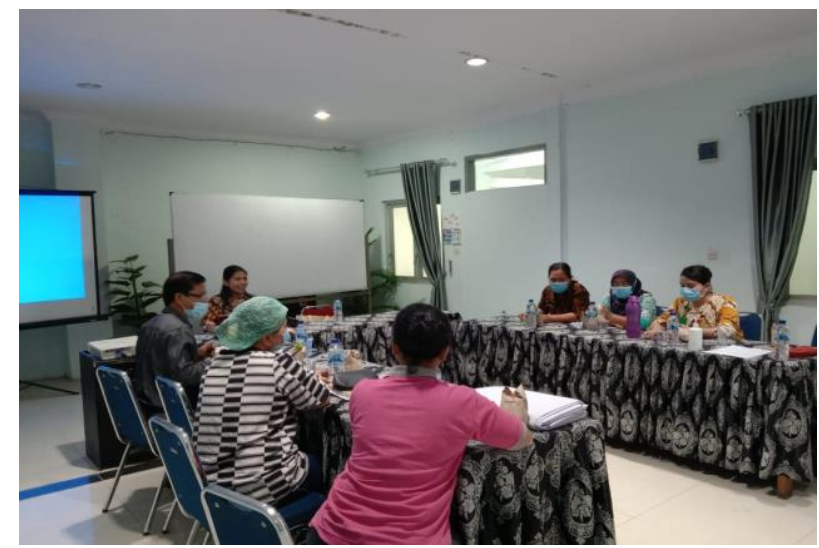

Gambar 2. Diskusi Dua Arah Bersama Peserta

\section{Kesimpulan}

Kegiatan pengabdian ini meningkatkan pengetahuan perawat di RSU Sari Mutiara Lubuk Pakam tentang proses pembimbingan klinik dan Mini-Cex. Proses pendampingan mahasiswa praktek yang tadinya hanya menerapkan metode konvensional atau metode yang sejak dulu kala seperti hanya rutinitas. Sejak kegiatan berlangsung menjadi lebih paham dan percaya diri untuk membmbing mahasiswa yang praktek.

Mini-Cex akan diterapkan sebagai upaya memfasilitasi mahasiswa untuk meningkatkan ketrampilan klinik dan menjalankan tahap klinik dengan baik. 


\section{Ucapan Terima Kasih}

Terima kasih kepada seluruh pihak yang telah membantu terlaksananya kegiatan pengabdian masyarakat ini kepada seluruh perawat di RSU Sari Mutiara Lubuk Pakam dan terutama Direksi RSU Sari Mutiara Lubuk Pakam yang telah mengijinkan kegiatan ini

\section{Daftar Referensi}

Howley, L. D., \& Wilson, W. G. (2004). Direct Observation of Students during Clerkship Rotations: A Multiyear Descriptive Study. Academic Medicine, 79(3), 276-280. https://doi.org/10.1097/00001888-200403000-00017

Martina, S. E., \& Simanjuntak, E. H. (2020). Peningkatan Keterampilan Klinik Melalui Penerapan Mini-CEX pada Mahasiswa Keperawatan Improvement Clinical Skill Through the Implementation of Mini-CEX among Nursing Student. 7(3), 137-141.

Norcini, J. J., Blank, L. L., Arnold, G. K., \& Kimball, H. R. (2003). The mini-CEX (clinical evaluation exercise): A preliminary investigation. Annals of Internal Medicine, 123(10), 795-799. https://doi.org/10.7326/0003-4819-123-10-199511150-00008

Nursalam, D. (2014). Manajemen Keperawatan" Aplikasi dalam Praktik Keperawatan Profesional. http://repository.stikesrspadgs.ac.id/377/1/0 BUKU MANAJEMEN-MAK 165 197.pdf

Sulistiawati. (2016). Umpan Balik pada Mini-CEX Feedback in Mini-CEX. JK Unila, 1(2), 413-417.

Tokode, O. M., \& Dennick, R. (2013). A qualitative study of foundation doctors' experiences with mini-CEX in the UK. International Journal of Medical Education, 4(1), 83-92. https://doi.org/10.5116/ijme.5165.e5d8 